\title{
ADAPTATION AND IMPROVING OF SUNFLOWER PLANT UNDER STRESS CONDITIONS AT TOSHKA REGION
}

\author{
A.S. Abd -Elnaby \\ Genetic Resources Dept., plant Adaptation Unit, Desert Research Center, Cairo, Egypt. \\ Received: Sep. 7, 2017
}

Accepted: Oct. 24, 2017

\begin{abstract}
Two field experiments were carried out in 2013 and 2014 growing seasons to investigate the role of some foliar application (Elga 600) at $1 / 2 \mathrm{~g} \Lambda$, (boron) at $1 \mathrm{~cm} \Lambda$, water, mixed from Elga 600 with boron and dry seed as a control and three date of planting ie $1^{\text {st }}$ august, $20^{\text {th }}$ august and $10^{\text {th }}$ September in adapting and improving sunflower (Helianthus annuus L.) plants $\mathrm{CV}$. Vidoc under saline conditions at the experimental station of desert research center Toshka Egypt. Two samples were taken at 60 days after sowing and at harvesting time (90 days after sowing).

Application of $10^{\text {th }}$ September as a sowing date of sunflower plant showed significant increase in all growth parameters compared with the other sowing dates during both seasons. Yield and its components surpassed with sowing date at $10^{\text {th }}$ September.

Applied foliar application with Elga (600) at $1 / 2 \mathrm{gm} /$ and (boron) at $1 \mathrm{~cm} \Lambda$ improve growth parameters, yield, yield components and nutritious value of sunflower plant as compared with control at growth and heading stages in 2012 and 2013 growing seasons. In the same direction Elga (600) at $1 / 2 \mathrm{gm} /$ and (boron) at $1 \mathrm{~cm}$ Las a foliar treatments may correct the metabolic disturbance under saline condition at experimental station 1nToshka Egypt which reflect on yield and its components. However, Elga (600) at $1 / 2 \mathrm{gm} /$ as a foliar treatment was better than(boron) at $1 \mathrm{~cm} \Lambda$ for improving the developmental traits and chemical composition $.10^{\text {th }}$ September as a sowing date significantly decreased Na concentrations and increased $K, K / N a$, and $P$ concentrations. Foliar applications of (Elga 600) at $1 / 2 \mathrm{gm} \Lambda$ or (boron) at $1 \mathrm{~cm} \Lambda$, decreased $\mathrm{Na}$ concentration and increased $\mathrm{K}, \mathrm{Ca}$ and $\mathrm{P}$ concentrations as well as K/Na ratio. All foliar applications significantly increased oil percentage and yield compared with the control. Regarding $10^{\text {th }}$ September as a sowing date and foliar application interactions all treatments enhanced the level of IAA and $G A_{3}$.
\end{abstract}

Key Words: Sunflower, Helianthus annuus L, Elga 600, boron, sowing date growth, yield, oil quality and mineral elements,

\section{INTRODUCTION}

Sunflower (Helianthus annuus L.) represents one of the main oil crops of the world . Being a thermos insensitive, grown in all seasons and producing oil resistant to rancidity and characterized by higher percent of unsaturated fatty acids ( El-Baz, 1995). In Egypt, there is a gap between production and consumption of plant oils. Increasing the cultivated areas of sunflower should be done in the reclaimed lands due to the limited areas of the Nile valley and the competition of the main crops. Thus the Experimental farm at Toshka Research station devoted to Desert Research Center was undertaken for the present investigation. This farm is characterized as highly calcareous soil (31.7 \% $\left.\mathrm{CaCO}_{3}\right)$, slightly saline (EC 2986 ppm), mildly alkaline $(\mathrm{pH} 7.9)$ and loamy in texture. Irrigation water is slightly saline (EC 2950.4 ppm salts). The presence of $\mathrm{CaCO}_{3}$ directly or indirectly affecting the chemistry and availability of Nitrogen $(\mathrm{N})$, Phosphorous $(\mathrm{P})$, potassium $(\mathrm{K})$, magnesium $(\mathrm{Mg})$, Iron $(\mathrm{Fe})$, Manganese (Mn) and Zinc ( $\mathrm{Zn}$ ), (Obreza et al., 1993).

On the other hand, salinity had deleterious effects on plant growth, development and even seed germination, 


\section{A.S. Abd -Elnaby}

particularly seed characteristic of sunflower, mainly oil content. Also, salinity influences nutrient uptake. Where salt concentration is low to moderate, the first visual symptom is often a thin stem and stunted growth Weiss . (2000).

Under these circumstances, potassium, phosphorus and zinc play an important role in improving the plant growth and subsequently, the yield of oil crops. Sakr et al. (1990) reported that, application of $P$ as mono calcium phosphate gave the highest dry matter yield in barley and sunflower plants under calcareous soil. Moreover, Harmati (1993) stated that $\mathrm{P}_{2} \mathrm{O}_{5}$ and $\mathrm{K}$ applications increased achene and oil yield of sunflower plants. Badawy (1990) investigated the effect of $\mathrm{P}$ on the growth and yield of soybean plants. He found that $P$

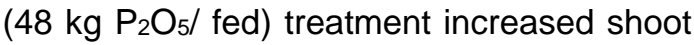
dry weight and seed yield of soybean plants under calcareous soil $\left(34 \% \mathrm{CaCO}_{3}\right)$. Salama (1987) showed that, K fertilizer $(200 \mathrm{~kg} / \mathrm{h})$ increased achene and oil yields of sunflower plants on calcareous sandy soil. Application of microelements either as soil application or foliar spray provided the best treatments which improved growth and yield of sunflower plants (Hegazy, 2004).

In this respect, dry matter amount of maize plant increased with increasing $\mathrm{Zn}$ doses applied to each pot as $\mathrm{ZnSO}_{4} .7 \mathrm{H}_{2} \mathrm{O}$ in sandy calcareous and clay calcareous soils (Adiloglu, 2006).

The present study tended to improve growth and oil production of sunflower plants grown under saline conditions at Toshka Aswan governorate by using the combination of five foliar application (Elga 600 ) at $1 / 2 \mathrm{gm}$, (boron) at $1 \mathrm{~cm} \Lambda$ water, mixed from Elga 600 with boron, tap water, and dry seeds as a control ) under three sowing dates at $1^{\text {st }}, 20^{\text {th }}$ of august and $10^{\text {th }}$ of September in both seasons.

\section{MATERIALS AND METHODS}

Two Field experiment were conducted in Toshka Station, Desert Research Center in
2012 and 2013 growingseason. Such studies was conducts to investigate the effect of five different foliar application treatments with three dates of sowing on plant growth characters, yield and yield components of sunflower plant under saline conditions at Toshka region. Each experiment included 15 treatments, i.e. the combination of five foliar application (Elga 600 ) at $1 / 2 \mathrm{~g}$, (boron) at $1 \mathrm{~cm} \Lambda$ water, mixed from Elga 600 with boron, tap water, and dry seeds as a control) and three date of sowing at $1^{\text {st }}$ and $20^{\text {th }}$ of August and $10^{\text {th }}$ of September in both seasons.

\section{Elga 600:- \\ Soluble Seaweed Extract Powder}

Elga 600 is a complete natural extract finely derived from brown seaweed, which contains 70 minerals, 17 amino acids, 4 plant hormones, chelating agents and complex sugars. These naturally occurring nutrients and bioactive substances can provide multiple benefits to enhance yields, quality and vigor significantly for various plants. It is available in a $100 \%$ soluble powder, which reduces transport costs and can be used through different application methods, and suitable for both growers and formulation manufactures.

More importantly, Elga 600 is both nontoxic and environmental friendly which will increase marketable value for agricultural product.

\section{GUARANTEED ANALYSIS}

\begin{tabular}{|c|c|}
\hline Analysis of Elga 600 & $1(\mathrm{w} / \mathrm{w})$ \\
\hline Organic Matter & $45.0 \sim 55.0 \%$ \\
\hline Alginic Acid & $8 \sim 10 \%$ \\
\hline Total Nitrogen & $6.0 \%$ \\
\hline Phosphoru(p2o5) & $5 \%$ \\
\hline Potassium(K20) & $20 \%$ \\
\hline Mg & $0.06 \%$ \\
\hline Ca & $0.4 \sim 1.6 \%$ \\
\hline Fe & $0.15 \sim 0.3 \%$ \\
\hline Cu & $25 \sim 45 p p m$ \\
\hline S & $1.0 \sim 1.5 \%$ \\
\hline I & $300 \sim 600 p p m$ \\
\hline Soluble in Water & $100 \%$ \\
\hline pH & $9 \sim 10$ \\
\hline Specific gravity & $0.5 \sim 0.55 \mathrm{~g} / \mathrm{Cm} 3$ \\
\hline Odder & Seaweed-like \\
\hline Appearance & brownish powder \\
\hline
\end{tabular}


Four naturally occurring plant growth regulators, auxins, gibberellins, cytokinins and betaines found in Elga 600, play very important roles in cell division and the synthesis of protein, carbohydrate and chlorophyll. In addition, these plant growth regulators have a huge positive impact on resistance to stress, pest and disease through activating immune system.

Alginic acid, the major content of Elga 600 , stimulates activities of soil microorganisms, improves the water-holding capability of soil, protects chemical fertilizers from leaching or locking up and helps the formation of crumb .

Structure. Mannitol existing in Elga 600 is a powerful chelating agent which helps cations entry into plants and be absorbed by plants more easily. It is beneficial for plants to utilize chemical fertilizers more efficiently.

Treatments were arranged in split plot design with three replicates. The main plots were occupied by the three date of sowing treatments and five foliar application in the sub plots. Organic manure and calcium superphosphate fertilizers were added during soil preparation at the rate of $20 \mathrm{~m}^{3}$ and $31 \mathrm{Kg} \mathrm{P} 2 \mathrm{O}_{5} / \mathrm{fed}$ respectively. Two equal doses of ammonium nitrate $(33.5 \% \mathrm{~N})$ were added at a rate of $66 \mathrm{~kg} \mathrm{~N} / \mathrm{fed}$ twice after 20 and 45 days from sowing. Each experimental plot included 5 ridges, $60 \mathrm{~cm}$ apart with $3.5 \mathrm{~m}$ length, comprising an area of $10.5 \mathrm{~m}^{2}(1 / 400 \mathrm{fed})$. The soil type of the experimental site was loamy sand in texture with $\mathrm{pH} 7.7, \mathrm{CaCO}_{3} 30.4 \%$, organic matter $0.5 \%$ and E.C $10 \mathrm{mmhos} / \mathrm{cm}$. Sunflower seeds were obtained from Oil Crop Research Institute, Agriculture Research Center in Giza and were planted in hills at $25 \mathrm{~cm}$ apart at three dates of sowing at $1^{\text {st }}$ and $20^{\text {th }}$ of august and $10^{\text {th }}$ of September in both seasons, respectively, The drip irrigation system of GR16 was used and plants were irrigated daily using saline well water of about $4500 \pm 100$ ppm salinity. Foliar application treatments were sprayed twice at 30 and 60 days after sowing using tween 20 as welting agent. The plants were thinned to two plants per hill at 20 days after sowing date.

Two samples were taken. First sample was taken at 60 days after sowing and the following growth parameters were recorded; plant height, stem diameter, stem fresh and dry weights, leaves number, fresh and dry weights for leaves. Chemical analysis was conducted in leaves on the $7-8^{\text {th }}$ nodes from the top for determination of some elements ( $\mathrm{Na}, \mathrm{K}, \mathrm{Ca}$ and $\mathrm{P}$ ).

The second sample was taken at harvesting time (90 days after sowing) to determine yield components including, plant height (cm) head diameter, seeds number/head, seeds weight/ head, 100 seeds weight (gm.), straw yield(kglfed.) and the seeds yield (ton/ fed). Samples were dried in an oven at $70^{\circ} \mathrm{C}$ to calculate the dry matter. The dried and fresh materials for the first sample were grounded into a fine powder and used for chemical analysis (combined analysis of 2012 and 2013 for chemical constituents were used).

Soluble protein was measured photo metrically at $750 \mathrm{~mm}$. with folin-phenol reagent (Lowry et al 1951). The acid digests of dried powdered materials were analyzed for mineral determination. $\mathrm{Na}^{+}, \mathrm{K}^{+}$and $\mathrm{Ca}^{++}$ were measured by using the flame photometer "149" as described by Johanson and Ulrich (1959). Also, oil content of seeds was determined according to A.O.A.C. (1984) by using soxhlet apparatus and petroleum ether as an organic solvent. Phosphorus was determined according to Murphy and Riley (1962).

\section{Extraction of seed oils :-}

Three individual $10 \mathrm{~g}$ samples of crushed dry seeds of each sunflower treatment were refluxed with $300 \mathrm{~mL}$ of petroleum benzene in weighed flasks using a Soxhlet apparatus according to the AACC (1987) method. The oils were recovered by distilling the solvent in a rotary evaporator at 
$45^{\circ} \mathrm{C}$, then dried to constant weight in a vacuum oven at $90^{\circ} \mathrm{C}$, for $1 \mathrm{~h}$ and weighed.

\section{Determination of plant hormones}

The purified samples were methylated with diazomethane (Schlenk and Gelerman, 1960) dissolved in ethyl ether and methanol $(9: 1 \mathrm{v} / \mathrm{v})$. The derivatives were dried under vacuum and re-dissolved in $100 \mu \mathrm{l}$ of EtOAc for GC analysis.

\section{Statistical Analysis:-}

Data were subjected to statistical analysis according to Gomez and Gomez (1984), LSD was used to detect significant differences at 0.05 level.

\section{RESULTS AND DISCUSSION 1- Growth characters: 1-1-Effect of sowing date}

Sowing dates on growth parameters of sunflower plants was presented in Table (1). $10^{\text {th }}$ September sowing dates showed significant increase in plant height, stem diameter, and stem fresh and dry weights during the two successive seasons. Also, leaves number, leaves fresh and dry weights tack the same trend. These results may be due to the essential role of late of planting sunflower plant which reflect on development of meristem tic tissues (Russell, 1973). Such response was noticed by El- Baisary et al. (1981) in cowpea plants grown under calcareous soil.

The maximum mean values of stem diameter $(5.79 \mathrm{~cm})$, shoot fresh weight (427.14 g/ plant) and shoot dry weight (99.44 g/plant) was achieved by sowing sun flower on $10^{\text {th }}$ September as Compared with sowing sunflower on $1^{\text {st }}$ August or 20 August in both seasons. . This finding is in harmony with that obtained by Aboul- Magd (1999) on tomato plants. The interpretation for this promotive effect may be related to for the late of planting sunflower on $10^{\text {th }}$ September at this time increases the photosynthetic rates, $\mathrm{CO}_{2}$ assimilation (Sangakkara et al., 2000) and has an important role in the translocation of photosynthates from source to sink (Cakmak et al., 1994). Furthermore, climatic etchings plays an important role in the osmotic adjustment for plant under saline conditions to maintain the selectivity and integrity of cell membrane (Satti and Lopez, 1994).

Table (1): Effect of sowing dates treatment on growth traits of sunflower at 60 days from sowing under Toshka conditions in 2012 and 2013 seasons.

\begin{tabular}{|c|c|c|c|c|c|c|c|}
\hline \multirow{2}{*}{$\begin{array}{l}\text { treatments } \\
\text { Sowing dates }\end{array}$} & \multirow{2}{*}{$\begin{array}{l}\text { Plant } \\
\text { height } \\
\text { (avg.) }\end{array}$} & \multicolumn{3}{|c|}{ Stem / plant } & \multicolumn{3}{|c|}{ Leaves / plant } \\
\hline & & $\begin{array}{l}\text { Diameter } \\
(\mathrm{cm})\end{array}$ & $\begin{array}{c}\text { Fresh } \\
\text { weight } \\
\text { (g) }\end{array}$ & $\begin{array}{c}\text { Dry } \\
\text { weight } \\
\text { (g) }\end{array}$ & Number & $\begin{array}{c}\text { Fresh } \\
\text { weight } \\
\text { (g) }\end{array}$ & $\begin{array}{c}\text { Dry } \\
\text { weight } \\
\text { (g) }\end{array}$ \\
\hline \multicolumn{8}{|c|}{2012} \\
\hline $1^{\text {st }}$ August & 135.68 & 3.862 & 299.56 & 72.656 & 33.15 & 187.26 & 33.6 \\
\hline $20^{\text {th }}$ August & 142.86 & 4.068 & 362.46 & 93.382 & 29.796 & 231.16 & 56.95 \\
\hline $10^{\text {th }}$ September & 147.22 & 4.672 & 427.14 & 105.94 & 32.852 & 243.84 & 61.366 \\
\hline L.S.D. 5\% & 0.40 & 0.02 & 19.43 & 0.811 & 1.55 & 13.81 & 0.52 \\
\hline \multicolumn{8}{|c|}{2013} \\
\hline $1^{\text {st }}$ August & 132.02 & 4.81 & 309.36 & 75.92 & 26.132 & 192.06 & 49.192 \\
\hline $20^{\text {th }}$ August & 142 & 5.012 & 314.48 & 79.02 & 34.666 & 218.2 & 55.664 \\
\hline $10^{\text {th }}$ September & 161.16 & 5.79 & 345.4 & 99.44 & 38.626 & 236.9 & 59.992 \\
\hline L.S.D. $5 \%$ & 1.03 & 0.43 & 21.02 & 10.21 & 1.21 & 10.26 & 0.44 \\
\hline
\end{tabular}




\section{1-2 Effect of foliar application:-}

Table (2) showed that the effect of foliar application of caborn and Elga 600 nutrients on growth parameters of sunflower plants. Application of Elga and boron showed significant increase in plant height and stem diameter during the two successive seasons. These results may be due to the essential role of Elga in cell division and development of meristematic tissues (Russell, 1973). Also, Elga 600 treatment did not significantly affect for shoot fresh and dry weights in both seasons. Such response was noticed by El- Baisary et al. (1981) in cowpea plants grown under calcareous soil.

The maximum mean values of stem diameter $(4.95 \mathrm{~cm})$, shoot fresh weight (405.40 g/ plant) and shoot dry weight (102.95 g/plant) was achieved by (Elga 600) compared to untreated plants which recorded $3.45 \mathrm{~cm}, 316.40 \mathrm{~g}$ and $82.27 \mathrm{~g}$ respectively in 2012 . The same trend was noticed in the second season. This finding is in harmony with that obtained by AboulMagd (1999) on tomato plants. The interpretation for this promotive effect of $\mathrm{K}$ on sunflower growth is that, $\mathrm{K}$ increases the photosynthetic rates, $\mathrm{CO}_{2}$ assimilation (Sangakkara et al., 2000) and has an important role in the translocation of photosynthates from source to sink (Cakmak et al., 1994). Furthermore, $K$ plays an important role in the osmotic adjustment for plant under saline conditions to maintain the selectivity and integrity of cell membrane (Satti and Lopez, 1994). Also, leaves number, leaves fresh and dry weights for leaves.

Table (2): Effect of foliar application treatments on growth traits of sunflower at 60 days from sowing under Toshka conditions in 2012and 2013 seasons.

\begin{tabular}{|c|c|c|c|c|c|c|c|}
\hline \multirow{2}{*}{$\begin{array}{l}\text { Treatments } \\
\text { Foliar application }\end{array}$} & \multirow{2}{*}{$\begin{array}{l}\text { Plant } \\
\text { height } \\
\text { (avg.) }\end{array}$} & \multicolumn{3}{|c|}{ Stem } & \multicolumn{3}{|c|}{ Leaves } \\
\hline & & $\begin{array}{l}\text { Diameter } \\
\text { (cm) }\end{array}$ & $\begin{array}{l}\text { Fresh } \\
\text { weight } \\
\text { (g) }\end{array}$ & $\begin{array}{c}\text { Dry } \\
\text { weight } \\
\text { (g) }\end{array}$ & Number & $\begin{array}{l}\text { Fresh } \\
\text { weight } \\
(\mathrm{g})\end{array}$ & $\begin{array}{c}\text { Dry } \\
\text { weight } \\
\text { (g) }\end{array}$ \\
\hline \multicolumn{8}{|c|}{2012} \\
\hline Control (Dry) & 133.7 & 3.45 & 316.4 & 82.27 & 24.49 & 195.8 & 42.45 \\
\hline Tap Water & 137.7 & 3.97 & 348.7 & 85.5 & 26.57 & 203.9 & 46.45 \\
\hline Caborn $\left(1 \mathrm{Cm}^{3} / \mathrm{L}\right.$ & 145.2 & 4.51 & 383.6 & 93.85 & 31.48 & 233.1 & 54.68 \\
\hline Elga $600(1 / 2 \mathrm{~cm} /)$ & 150.2 & 4.95 & 405.4 & 102.95 & 34.34 & 257.6 & 60.17 \\
\hline Caborn +Elga 600 & 142.7 & 4.12 & 362 & 88.73 & 27.78 & 213.4 & 49.44 \\
\hline L.S.D. $5 \%$ & 0.45 & 0.2 & 14.02 & 0.62 & 0.96 & 13.32 & 0.22 \\
\hline \multicolumn{8}{|c|}{2013} \\
\hline Control (Dry) & 134.43 & 4.62 & 271.93 & 69.21 & 27.07 & 195.4 & 49.19 \\
\hline Tap Water & 144.16 & 5.00 & 321.4 & 81.43 & 31.30 & 208.73 & 53.31 \\
\hline Caborn(1Cm³/L) & 141.83 & 5.41 & 333.9 & 82.94 & 35.50 & 223.5 & 57.52 \\
\hline Elga $600(1 / 2 \mathrm{~cm} /)$ & 156.06 & 5.79 & 361.6 & 91.18 & 38.56 & 234.17 & 59.51 \\
\hline Caborn+Elega 600 & 148.8 & 5.19 & 326.53 & 78.38 & 33.28 & 216.77 & 55.20 \\
\hline L.S.D. $5 \%$ & 0.52 & 0.02 & 9.31 & 0.33 & 1.20 & 9.32 & 0.18 \\
\hline
\end{tabular}




\section{1-3- Effect of interaction :-}

Regarding the effect of the interactions between date of planting and folair application (Table 3) on plant height, stem diameter, stem fresh and dry weights, leaves number, leaves fresh and dry weights in 2012 and 2013, growing season a significant increase were obtained by all treatments. Moreover, $10^{\text {th }}$ September as a planting date with spray Elega600treatment interaction showed the maximum significant values which reached, $158.3 \mathrm{~cm}, 5.71 \mathrm{~cm}$, 486.3 g. 120.60 g, 40.70, 295.7g,74.13g comparing with control plants ( $1^{\text {st }}$ August as a planting date $x$ without spray treatment interaction) which recorded $122.5 \mathrm{~cm}, 3.35$ $\mathrm{cm}, 247.5$ g.60.10 g,18.16178.5g ,28.15 g respectively for all growth parameters ( plant height, stem diameter ,stem fresh and dry weights, leaves number, leaves fresh and dry weight) during the $1^{\text {st }}$ season. The same trend was achieved in the $2^{\text {nd }}$ season.

These results were in agreement with $\mathrm{Wu}$ et al. (1999) who revealed that $\mathrm{K}$ and trace elements application increased $P$ concentration in soybean. Insignificant increments in $\mathrm{Mg}$ concentration were noticed by all treatments. Also, an increase in $\mathrm{Mg}$ concentration of Sudan grass plants was mentioned by Kishk et al. (1985) as a result of $\mathrm{Zn}$ application under calcareous soil $\left(30 \% \mathrm{CaCO}_{3}\right)$ with salinity.

Also, Ozoris et al. (1985) who reported that the concentration of $\mathrm{K}^{+}$and $\mathrm{Mg}^{+2}$ in sorghum plants were increased by application of $\mathrm{Zn}$ under calcareous soil and saline conditions. The role of $\mathrm{K}$ in the osmotic adjustment of plants under saline conditions and consequently its importance of being required to the selectivity and integrity of cell membrane was explained by (Satti and Lopez, 1994).

\section{2- Yield and yield components:- 2-1-Effect of sowing dates:-}

Data in Table (4) showed that, $10^{\text {th }}$ September as a date of planting significant increased head diameter, number of seeds/ head, seeds weight/ head, 1000 seeds weight and seeds yield/fed. Compared with the both date of planting 1n 2012 and 2013 growing seasons. However $20^{\text {th }}$ august as a sowing date recorded the second order except seed yield fed. during $1^{\text {st }}$ season and 1000 seed weight 1 n 2013growing season. The positive effect for all characters for sunflower plants during $2^{\text {nd }}$ season compared with the $1^{\text {st }}$ one .

These results may be due to the essential role of late of planting sunflower plant which reflect on development of meristem in tissues (Russell, 1973). Such response was noticed by El- Baisary et al. (1981) in cowpea plants grown under calcareous soil. Also, these results were in agreement with Hegazy (2004) on sunflower and Sawan et al. (2006) on seeds yield of Egyptian cotton. Also, planting sunflower plant during $10^{\text {th }}$ September led to the moisture in the soil more, than the other sowing date which reflect on yield and its components in this regard Vitkov (1976) reported that the highest sunflower seed and straw yields were In addition, increasing soil moisture content increased seed yield and 100 seed weight of sunflower plants. (Muriel et al., 1977)

Sarkar and Bhattacharya (1980) observed that good yield was obtained when sunflower was irrigated at $60 \%$ of available soil moisture.

Moreover, El-Sawaby and Zekril (1982) added that the highest yield of sunflower was gained by raising soil moisture at field capacity every 14 days.

\section{2-2-Effect of foliar application:-}

Data presented in Table (5) indicated that all sunflower yield and its attributes markedly responded to boron and Elga spraying treatments, compared with control. 
Table (3): Effect of the interaction between Sowing dates and different foliar application on growth traits of sunflower at 60 days from sowing under Toshka conditions in 2012and 2013 seasons.

\begin{tabular}{|c|c|c|c|c|c|c|c|c|}
\hline \multicolumn{2}{|l|}{ Treatments } & \multirow{2}{*}{$\begin{array}{c}\text { Plant } \\
\text { height } \\
\text { (avg.) }\end{array}$} & \multicolumn{3}{|c|}{ Stem } & \multicolumn{3}{|c|}{ Leaves } \\
\hline $\begin{array}{l}\text { Sowing } \\
\text { dates }\end{array}$ & Foliar application & & $\begin{array}{l}\text { Diameter } \\
(\mathrm{cm})\end{array}$ & \begin{tabular}{|c|} 
Fresh \\
weight \\
$(\mathrm{g})$
\end{tabular} & $\begin{array}{c}\text { Dry } \\
\text { weight } \\
\text { (g) }\end{array}$ & Number & $\begin{array}{c}\text { Fresh } \\
\text { weight } \\
(\mathrm{g})\end{array}$ & $\begin{array}{c}\text { Dry } \\
\text { weight } \\
\text { (g) }\end{array}$ \\
\hline \multicolumn{9}{|c|}{2012} \\
\hline \multirow[t]{5}{*}{$1^{\text {st }}$ August } & Control (Dry) & 122.5 & 3.35 & 247.5 & 60.10 & 18.16 & 178.5 & 28.15 \\
\hline & Tap Water & 130.6 & 3.78 & 305.5 & 70.10 & 22.12 & 181.6 & 31.25 \\
\hline & Caborn $\left(1 \mathrm{Cm}^{3} / \mathrm{L}\right.$ & 140.5 & 4.03 & 315.8 & 75.35 & 27.16 & 190.5 & 35.85 \\
\hline & Elga600(1/2cmlL) & 144.0 & 4.43 & 318.5 & 85.13 & 30.16 & 200.5 & 39.25 \\
\hline & Caborn +Elga 600 & 140.8 & 3.72 & 310.5 & 72.6 & 23.15 & 185.2 & 33.5 \\
\hline \multirow[t]{5}{*}{$20^{\text {th }}$ August } & Control (Dry) & 138.7 & 3.40 & 339.6 & 96.2 & 27.20 & 200.5 & 48.1 \\
\hline & Tap Water & 140.0 & 3.93 & 340.2 & 85.9 & 28.45 & 210.9 & 52.5 \\
\hline & Caborn $\left(1 \mathrm{Cm}^{3} / \mathrm{L}\right.$ & 144.6 & 4.50 & 375.7 & 94.2 & 31.16 & 242.5 & 60.6 \\
\hline & Elga600(1/2cmlL) & 148.4 & 4.71 & 411.3 & 103.11 & 32.17 & 276.7 & 67.13 \\
\hline & Caborn +Elga 600 & 142.6 & 3.80 & 345.5 & 87.50 & 30.00 & 225.5 & 56.42 \\
\hline \multirow{5}{*}{$\begin{array}{l}10^{\text {th }} \\
\text { September }\end{array}$} & Control (Dry) & 140.0 & 3.60 & 362.2 & 90.50 & 28.10 & 208.5 & 51.1 \\
\hline & Tap Water & 142.4 & 4.20 & 400.5 & 100.50 & 29.14 & 219.3 & 55.60 \\
\hline & Caborn $\left(1 \mathrm{Cm}^{3} / \mathrm{L}\right.$ & 150.6 & 5.00 & 456.7 & 112.00 & 36.12 & 266.2 & 67.60 \\
\hline & Elga600(1/2cmlL) & 158.3 & 5.71 & 486.3 & 120.60 & 40.70 & 295.7 & 74.13 \\
\hline & Caborn +Elga 600 & 144.8 & 4.85 & 430.0 & 106.10 & 30.20 & 229.5 & 58.40 \\
\hline \multicolumn{2}{|l|}{ L.S.D. $5 \%$} & 0.11 & 0.50 & 0.53 & 0.12 & 0.13 & 4.20 & 1.2 \\
\hline \multicolumn{9}{|c|}{2013} \\
\hline \multirow[t]{5}{*}{$1^{\text {st }}$ August } & Control (Dry) & 122.5 & 4.35 & 254.5 & 65.12 & 20.11 & 183.5 & 46.13 \\
\hline & Tap Water & 131.8 & 4.62 & 315.5 & 80.10 & 24.12 & 186.6 & 47.93 \\
\hline & Caborn $\left(1 \mathrm{Cm}^{3} / \mathrm{L}\right.$ & 114.4 & 4.93 & 322.8 & 78.35 & 29.16 & 195.5 & 51.15 \\
\hline & Elga600(1/2cm/) & 148.1 & 5.33 & 338.5 & 84.43 & 32.14 & 205.5 & 51.24 \\
\hline & Caborn +Elga 600 & 143.3 & 4.82 & 315.5 & 71.60 & 25.13 & 189.2 & 49.51 \\
\hline \multirow[t]{5}{*}{$20^{\text {th }}$ August } & Control (Dry) & 136.2 & 4.50 & 261.2 & 66.30 & 27.10 & 191.6 & 48.25 \\
\hline & Tap Water & 141.2 & 4.90 & 317.5 & 82.50 & 33.25 & 219.2 & 55.40 \\
\hline & Caborn $\left(1 \mathrm{Cm}^{3} / \mathrm{L}\right.$ & 144.6 & 5.30 & 326.6 & 80.46 & 37.02 & 224.2 & 57.60 \\
\hline & Elga600 $(1 / 2 \mathrm{~cm} /)$ & 147.5 & 5.41 & 346.3 & 88.61 & 40.76 & 235.5 & 61.14 \\
\hline & Caborn +Elga 600 & 140.5 & 4.95 & 320.8 & 77.23 & 35.20 & 220.5 & 55.93 \\
\hline \multirow{5}{*}{$\begin{array}{l}10^{\text {th }} \\
\text { September }\end{array}$} & Control (Dry) & 144.6 & 5.01 & 300.2 & 76.22 & 34.00 & 211.1 & 53.18 \\
\hline & Tap Water & 159.5 & 5.50 & 331.2 & 81.70 & 36.54 & 220.4 & 56.62 \\
\hline & Caborn $\left(1 \mathrm{Cm}^{3} / \mathrm{L}\right.$ & 166.5 & 6.00 & 352.3 & 90.00 & 40.31 & 250.9 & 63.83 \\
\hline & Elga600(1/2cm/) & 172.6 & 6.63 & 400.0 & 100.5 & 42.78 & 261.5 & 66.16 \\
\hline & Caborn +Elga 600 & 162.6 & 5.81 & 343.3 & 86.30 & 39.50 & 240.6 & 60.17 \\
\hline \multicolumn{2}{|l|}{ L.S.D. $5 \%$} & 0.10 & 0.02 & 0.38 & 0.07 & 0.08 & 3.16 & 0.05 \\
\hline
\end{tabular}


Table (4): Effect of sowing dates treatment on yield and yield components of sunflower at harvesting date under Toshka conditions in 2012and 2013 seasons.

\begin{tabular}{|c|c|c|c|c|c|c|c|}
\hline \multirow[t]{2}{*}{ Treatments } & \multirow{2}{*}{$\begin{array}{l}\text { Plant } \\
\text { height } \\
\text { (avg.) }\end{array}$} & \multicolumn{4}{|c|}{ Head } & \multicolumn{2}{|c|}{ Yield (kg/fed) } \\
\hline & & $\begin{array}{l}\text { Diameter } \\
(\mathrm{cm})\end{array}$ & $\begin{array}{c}\text { Seed } \\
\text { number }\end{array}$ & $\begin{array}{c}\text { Seed } \\
\text { weight (g) }\end{array}$ & $\begin{array}{c}\text { Weight of } \\
1000 \text { seed } \\
\text { (g) }\end{array}$ & Straw & Seed \\
\hline \multicolumn{8}{|c|}{2012} \\
\hline $1^{\text {st }}$ August & 150.9 & 19.44 & 991.1 & 83.072 & 71.98 & 1752.8 & 753.93 \\
\hline $20^{\text {th }}$ August & 161.5 & 22.04 & 1208.8 & 104.80 & 85.66 & 2018.2 & 745.87 \\
\hline $10^{\text {th }}$ September & 166.1 & 23.7 & 1325.4 & 140.14 & 96.932 & 2439.4 & 1247.93 \\
\hline L.S.D. $5 \%$ & 1.04 & 0.20 & 33.0 & 0.42 & 3.02 & 33.43 & 4.22 \\
\hline \multicolumn{8}{|c|}{2013} \\
\hline $1^{\text {st }}$ August & 154.2 & 20.76 & 1009.4 & 87.05 & 364.85 & 1764.3 & 823.112 \\
\hline $20^{\text {th }}$ August & 162.2 & 22.24 & 1397.1 & 112.47 & 96.62 & 2068.6 & 971.18 \\
\hline $10^{\text {th }}$ September & 172.3 & 23.52 & 1271.2 & 111.8 & 101.96 & 2465.0 & 1258.09 \\
\hline L.S.D. 5 \% & 1.10 & 0.30 & 10.22 & 0.40 & 4.00 & 23.31 & 6.02 \\
\hline
\end{tabular}

Table (5): Effect of foliar application on yield and yield components of sunflower at harvesting date under Toshka conditions in 2012and 2013 seasons.

\begin{tabular}{|c|c|c|c|c|c|c|c|}
\hline \multirow[t]{2}{*}{ Treatments } & \multirow{2}{*}{$\begin{array}{l}\text { Plant } \\
\text { height }\end{array}$} & \multicolumn{4}{|c|}{ Head } & \multicolumn{2}{|c|}{ Yield (kg/fed) } \\
\hline & & $\begin{array}{l}\text { Diameter } \\
\quad(\mathrm{cm})\end{array}$ & $\begin{array}{l}\text { Seed } \\
\text { number }\end{array}$ & $\begin{array}{l}\text { Seed } \\
\text { weight } \\
\text { (g) }\end{array}$ & $\begin{array}{l}\text { Weight } \\
\text { of } 1000 \\
\text { seed }(\mathrm{g})\end{array}$ & Straw & Seed \\
\hline \multicolumn{8}{|l|}{2012} \\
\hline Control (Dry) & 156.2 & 20.13 & 1077.6 & 92.74 & 79.52 & 1956.44 & 858.45 \\
\hline Tap Water & 159.03 & 21.26 & 1136.8 & 99.95 & 82.7 & 1985.43 & 930.38 \\
\hline Cab. $\left(1 \mathrm{Cm}^{3} / \mathrm{L}\right.$ & 161.63 & 22.3 & 1229.2 & 117.06 & 89.15 & 2125.13 & 1041.11 \\
\hline Elga $600(1 / 2 \mathrm{~cm} /)$ & 164.3 & 24.26 & 1284.1 & 126.16 & 93.18 & 2217.55 & 1103.5 \\
\hline Cab.+Elga600 & 159.4 & 21.33 & 1147.7 & 110.8 & 86.40 & 2066.06 & 979.43 \\
\hline L.S.D. 5 \% & 0.72 & 0.22 & 8.32 & 0.51 & 2.10 & 13.07 & 11.03 \\
\hline \multicolumn{8}{|c|}{2013} \\
\hline Control (Dry) & 158.9 & 21.4 & 1134.8 & 86.6 & 83.9 & 1956.4 & 897.6 \\
\hline Tap Water & 164.06 & 21.6 & 1193.9 & 100.63 & 87.3 & 2085.4 & 991.75 \\
\hline Cab. $\left(1 \mathrm{Cm}^{3} / \mathrm{L}\right.$ & 161.73 & 22.63 & 1268.9 & 112.2 & 93.6 & 2143.82 & 1039.56 \\
\hline Elga600(1/2cm/) & 167.4 & 11.6 & 1321.1 & 118.9 & 99.7 & 2229.4 & 1110.24 \\
\hline Cab.+Elga600 & 162.4 & 22.03 & 1210.9 & 100.56 & 88.13 & 2049.05 & 948.14 \\
\hline L.S.D. $5 \%$ & 0.55 & 0.30 & 3.05 & 0.46 & 1.00 & 11.05 & 10.33 \\
\hline
\end{tabular}


Application of Elga $6001 / 2 \mathrm{~cm}$ as foliar spraying recorded the maximal significant values of yield and its components. Such efficient treatment increased head diameter, seeds number/head, seed weight/head, 1000 -seed weight and yields of biological, straw and seed/fed. By 20.5, 19.2, 36.0, $17.2,5.6,4.2$ and $28.5 \%$, respectively, compared to control during $1^{\text {st }}$ season. Moreover, spraying of boron recorded the second order in this respect, and enhanced the mentioned traits by $2.5,10.8,14.1,26.2$, $12.1,8.6$ and $21.3 \%$, respectively, than the control (without boron) in 2012 growing season. However all characters for yield and its components tack the same trend in 2013 growing season. It is clear that the increase in boron level improved sunflower yield and its attributes. Boron fertilization stimulated vegetative growth traits of sunflower plants (Table, 5 ), and this in turn increased photosynthetic areas and activity as well as dry matter accumulation in seeds and heads. Similar results were obtained by Tamak et. al. (1997), Vyakaranahal et. al. (2001) and El-Sadek et. al. (2004). The spraying of boron at the rate of $339 \mathrm{ppm}$ secured the highest values of harvest index, crop index and water use efficiency, exceeding the other treatments in this respect.

Concerning the effect of Elga600 application, it is obvious from data in Table (5) that significantly enhanced all yield parameters in both seasons except head diameter which showed insignificant increase in the first season. These results confirmed the findings of Salama (1987) and Mekki et al. (1999) on sunflower plants. However, Elga600 is required as cofactor for many enzymes involved in respiration and photosynthesis. Thus, an enhancement in carbon fixation and energy production would gain by Elga600 application which positively affect oil seed yield.

\section{2-3- Effect of interaction:-}

The interaction between sowing date and spraying boron and Elga 600 interaction divulged remarkable effect on sunflower yield and its components (Table 6). In this respect, the combination of $10^{\text {th }}$ September as a sowing date $x$ Elga 600 recorded the maximum values of plant height, head diameter, seeds number/head, seed weight/head, 1000-seed weight, biological yield and seed yields/fed. Compared with the other treatments during both seasons. Additionally, under the same sowing date with boron spraying interaction recorded the $2^{\text {nd }}$ one for improving yield and its components in 2012 and 2013 growing season. Otherwise, $1^{\text {st }}$ August as a sowing date with dry seeds interaction (without any spraying) gave the minimal values of all yield and yield components .

\section{3- Chemical constituents:- 3-1-Effect of Sowing date:-}

Data in Table (7) clearly demonstrated that, planting sunflower plant during $10^{\text {th }}$ September, protein yield and protein percentages, oil yield and oil percentages as well as mineral recorded the highest significant mean values as compared with the both sowing date ( $1^{\text {st }}$ and $20^{\text {th }}$ August) . Meanwhile $\mathrm{Na}$ content tack the adverse effect. However, planting sunflower plant during $1^{\text {st }}$ and $20^{\text {th }}$ August detected the $2^{\text {nd }}$ and $3^{\text {rd }}$ order for chemical constituents.

\section{3-2-Effect of Foliar application:-}

As shown in Table (7), spray Elga 600 marked the highest significant mean values for protein yield and protein percentage as compared with different foliar application treatments. Also, oil yield and oil percentages gave the trend. However, mineral content $\mathrm{K}, \mathrm{Ca}$ and $\mathrm{P}$ surpassed with Elga 600 and boron as a foliar application with seed sunflower plant compared with the control. Whereas, $\mathrm{Na}$ content tack the adverts effect under different foliar application. 
Table (6): Effect of foliar application and different sowing dates treatments on yield and yield components of sunflower at harvesting dates under Toshka conditions in 2012 and 2013 seasons.

\begin{tabular}{|c|c|c|c|c|c|c|c|c|}
\hline \multicolumn{2}{|l|}{ Treatments } & \multirow{2}{*}{$\begin{array}{c}\text { Plant } \\
\text { height }\end{array}$} & \multicolumn{4}{|c|}{ Head } & \multicolumn{2}{|c|}{ Yield (kg/fed) } \\
\hline $\begin{array}{l}\text { Sowing } \\
\text { dates }\end{array}$ & Foliar application & & $\begin{array}{c}\text { Diameter } \\
(\mathrm{cm})\end{array}$ & $\begin{array}{c}\text { Seed } \\
\text { number }\end{array}$ & $\begin{array}{c}\text { Seed } \\
\text { weight } \\
(\mathrm{g})\end{array}$ & $\begin{array}{c}\text { Weight } \\
\text { of } 1000 \\
\text { seed } \\
(\mathrm{g})\end{array}$ & Straw & Seed \\
\hline \multicolumn{9}{|c|}{2012} \\
\hline \multirow[t]{5}{*}{$1^{\text {st }}$ August } & Control (Dry) & 144.6 & 18.2 & 855.4 & 61.66 & 62.50 & 1598.22 & 589.50 \\
\hline & Tap Water & 150.6 & 18.8 & 936.5 & 71.20 & 66.75 & 1650.45 & 645.80 \\
\hline & Caborn $\left(1 \mathrm{Cm}^{3} / \mathrm{L}\right.$ & 152.6 & 20.6 & 1075.2 & 96.50 & 77.50 & 1833.12 & 855.35 \\
\hline & Elga600(1/2cmlL) & 155.2 & 22.0 & 1145.6 & 102.60 & 81.60 & 1855.60 & 905.30 \\
\hline & Caborn +Elga600 & 151.5 & 19.6 & 942.6 & 83.40 & 71.60. & 1826.40 & 773.70 \\
\hline \multirow[t]{5}{*}{$20^{\text {th }}$ August } & Control (Dry) & 158.2 & 20.2 & 1166.5 & 91.36 & 82.50 & 1882.40 & 780.50 \\
\hline & Tap Water & 160.0 & 21.5 & 1188.3 & 95.75 & 83.60 & 1896.25 & 905.75 \\
\hline & Caborn $\left(1 \mathrm{Cm}^{3} / \mathrm{L}\right.$ & 162.5 & 22.2 & 1212.3 & 110.5 & 86.75 & 2085.16 & 1005.40 \\
\hline & Elga600(1/2cm/) & 166.6 & 24.5 & 1276.5 & 117.6 & 89.55 & 2296.75 & 1115.2 \\
\hline & Caborn +Elga600 & 160.4 & 21.8 & 1200.5 & 108.8 & 85.90 & 1930.50 & 922.5 \\
\hline \multirow{5}{*}{$\begin{array}{l}10^{\text {th }} \\
\text { September }\end{array}$} & Control (Dry) & 165.8 & 22.0 & 1210.8 & 125.2 & 93.56 & 2388.7 & 1205.35 \\
\hline & Tap Water & 166.5 & 23.5 & 1285.5 & 132.9 & 97.80 & 2409.60 & 1239.60 \\
\hline & Caborn.(1Cm $3 / \mathrm{L}$ & 169.8 & 24.1 & 1400.1 & 144.2 & 103.2 & 2457.10 & 1262.6 \\
\hline & Elga600(1/2cm/) & 171.0 & 26.3 & 1430.3 & 158.3 & 108.4 & 2500.3 & 1290.0 \\
\hline & Caborn +Elga600 & 166.2 & 22.6 & 1300.1 & 140.1 & 101.7 & 2441.3 & 1242.1 \\
\hline \multicolumn{2}{|l|}{ L.S.D. $5 \%$} & 0.32 & 0.24 & 4.09 & 0.51 & 1.07 & 13.00 & 9.04 \\
\hline \multicolumn{9}{|c|}{2013} \\
\hline \multirow[t]{5}{*}{$1^{\text {st }}$ August } & Control (Dry) & 147.5 & 19.9 & 862.5 & 65.85 & 62.70 & 1620.50 & 592.80 \\
\hline & Tap Water & 155.6 & 20.0 & 955.6 & 88.60 & 72.20 & 1835.20 & 798.60 \\
\hline & Cab. $\left(1 \mathrm{Cm}^{3} / \mathrm{L}\right.$ & 156.2 & 21.2 & 1096.0 & 98.50 & 78.80 & 1839.30 & 862.20 \\
\hline & Elga600(1/2cm/) & 159.5 & 22.0 & 1157.6 & 106.7 & 82.35 & 1866.70 & 911.12 \\
\hline & Caborn+Elga 600 & 152.3 & 20.7 & 975.5 & 75.60 & 68.80 & 1659.65 & 650.84 \\
\hline \multirow[t]{5}{*}{$20^{\text {th }}$ August } & Control (Dry) & 159.8 & 21.5 & 1301.2 & 93.75 & 90.20 & 1891.46 & 888.20 \\
\hline & Tap Water & 165.2 & 21.8 & 1335.6 & 103.2 & 89.50 & 1998.30 & 933.30 \\
\hline & Caborn $\left(1 \mathrm{Cm}^{3} / \mathrm{L}\right.$ & 155.6 & 22.9 & 1440.8 & 122.5 & 98.50 & 2092.18 & 981.50 \\
\hline & $\operatorname{Elga} 600(1 / 2 \mathrm{~cm} /)$ & 167.5 & 23.00 & 1505.6 & 129.5 & 109.50 & 2306.5 & 1119.6 \\
\hline & Cab.+Elga 600 & 162.8 & 22.00 & 1402.2 & 113.40 & 95.40 & 2000.5 & 933.3. \\
\hline \multirow{5}{*}{$\begin{array}{l}10^{\text {th }} \\
\text { September }\end{array}$} & Control (Dry) & 169.5 & 22.80 & 1240.6 & 100.2 & 98.80 & 2400.2 & 1211.80 \\
\hline & Tap Water & 171.4 & 23.00 & 1290.5 & 110.1 & 100.2 & 2422.7 & 1243.35 \\
\hline & Cab. $\left(1 \mathrm{Cm}^{3} / \mathrm{L}\right.$ & 173.4 & 23.80 & 1270.0 & 115.6 & 103.4 & 2500.0 & 1275.0 \\
\hline & Elga600(1/2cm/) & 175.2 & 24.6 & 1300.0 & 120.4 & 107.2 & 2515.0 & 1300.0 \\
\hline & Cab.+Elga 600 & 172.1 & 23.4 & 1255.0 & 112.7 & 100.2 & 2487.0 & 1260.3 \\
\hline \multicolumn{2}{|l|}{ L.S.D. 5 \% } & 0.11 & 0.18 & 2.65 & 0.43 & 1.02 & 11.21 & 6.28 \\
\hline
\end{tabular}


Table (7): Effect of sowing dates, foliar application treatments and their interactions on chemical constituents of sunflower seeds under saline soil at Toshka conditions.

\begin{tabular}{|c|c|c|c|c|c|c|c|c|c|}
\hline \multirow{2}{*}{\multicolumn{2}{|c|}{ Treatments }} & \multicolumn{2}{|c|}{ Protein } & \multicolumn{2}{|c|}{ Oil } & \multicolumn{4}{|c|}{ Mineral nutrients } \\
\hline & & $\begin{array}{l}\text { yield } \\
\mathrm{kg} / \mathrm{fed}\end{array}$ & $\%$ & $\begin{array}{c}\text { yield } \\
\mathrm{kg} / \mathrm{fed}\end{array}$ & $\%$ & $\begin{array}{c}\mathrm{Na} . \\
\mathrm{Mg} / \mathrm{g} \\
\text { weight }\end{array}$ & $\begin{array}{c}\mathrm{K} . . \\
\mathrm{Mg} / \mathrm{g} \\
\text { weight }\end{array}$ & $\begin{array}{c}\mathrm{Ca} . \\
\mathrm{Mg} / \mathrm{g} \\
\text { weight }\end{array}$ & \begin{tabular}{|c|}
$p$ \\
Mg/100g \\
weight
\end{tabular} \\
\hline \multicolumn{10}{|c|}{ Effect of sowing dates:- } \\
\hline \multicolumn{2}{|l|}{$1^{\text {st }}$ August } & 176.8 & 14.16 & 246.7 & 23.56 & 16.54 & 41.18 & 53.72 & 25.58 \\
\hline \multicolumn{2}{|l|}{$20^{\text {th }}$ August } & 179.3 & 15.06 & 254.9 & 23.58 & 16.36 & 42.10 & 55.04 & 25.76 \\
\hline \multicolumn{2}{|c|}{$10^{\text {th }}$ September } & 185.5 & 20.78 & 349.3 & 31.46 & 16.46 & 46.58 & 56.96 & 29.32 \\
\hline \multicolumn{2}{|l|}{ L.S.D. $5 \%$} & 2.02 & 3.14 & 6.08 & 0.30 & 0.02 & 0.11 & 0.42 & 0.05 \\
\hline \multicolumn{10}{|c|}{ Effect of foliar application :- } \\
\hline \multicolumn{2}{|c|}{ Control (Dry) } & 169.2 & 14.0 & 256.5 & 23.8 & 19.0 & 35.8 & 48.4 & 21.3 \\
\hline \multicolumn{2}{|l|}{ Tap Water } & 171.2 & 15.5 & 272.5 & 24.7 & 18.4 & 38.9 & 53.1 & 23.0 \\
\hline \multicolumn{2}{|c|}{ Caborn $\left(1 \mathrm{Cm}^{3} / \mathrm{L}\right.$} & 176.5 & 16.3 & 282.0 & 26.0 & 16.1 & 44.1 & 57.1 & 27.5 \\
\hline \multicolumn{2}{|c|}{ Elga $600(1 / 2 \mathrm{~cm} /)$} & 190.5 & 18.2 & 296.2 & 27.7 & 14.9 & 47.1 & 58.3 & 30.5 \\
\hline \multicolumn{2}{|c|}{ Caborn +Elga600 } & 195.4 & 19.2 & 310.8 & 28.7 & 13.9 & 50.5 & 59.2 & 32.0 \\
\hline \multicolumn{2}{|c|}{ L.S.D. $5 \%$} & 0.50 & 0.82 & 10.02 & 0.21 & 0.03 & 0.12 & 0.25 & 0.10 \\
\hline \multicolumn{10}{|c|}{ Effect of interaction:- } \\
\hline \multirow[t]{5}{*}{$1^{\text {st }}$ August } & Control (Dry) & 166.5 & 13.0 & 235.5 & 22.5 & 18.5 & 32.6 & 46.5 & 20.6 \\
\hline & Tap Water & 168.6 & 13.8 & 240.6 & 22.8 & 18.2 & 34.2 & 52.5 & 22.5 \\
\hline & $\begin{array}{l}\text { Caborn } \\
\left(1 \mathrm{Cm}^{3} / \mathrm{L}\right.\end{array}$ & 171.5 & 14.2 & 244.5 & 23.5 & 16.2 & 42.4 & 55.2 & 25.8 \\
\hline & Elga 600 & 185.6 & 14.6 & 251.2 & 24.2 & 15.8 & 46.5 & 56.8 & 28.4 \\
\hline & $\begin{array}{l}\text { Caborn +Elga } \\
600\end{array}$ & 191.8 & 15.2 & 261.5 & 24.8 & 14.0 & 50.2 & 57.6 & 30.6 \\
\hline \multirow[t]{5}{*}{$20^{\text {th }}$ August } & Control (Dry) & 169.2 & 13.5 & 238.5 & 22.5 & 18.8 & 34.2 & 48.6 & 20.8 \\
\hline & Tap Water & 169.5 & 14.2 & 246.5 & 23.2 & 18.0 & 38.2 & 52.9 & 22.4 \\
\hline & Cab. $\left(1 \mathrm{Cm}^{3} / \mathrm{L}\right.$ & 175.6 & 14.6 & 255.5 & 23.2 & 16.2 & 42.8 & 57.2 & 24.6 \\
\hline & Elga 600 & 190.2 & 16.2 & 261.6 & 24.2 & 14.6 & 46.5 & 58.0 & 30.2 \\
\hline & $\begin{array}{l}\text { Caborn +Elga } \\
600\end{array}$ & 192.2 & 16.8 & 272.3 & 24.8 & 14.2 & 48.8 & 58.5 & 30.8 \\
\hline \multirow[t]{5}{*}{$\begin{array}{c}10^{\text {th }} \\
\text { September }\end{array}$} & Control (Dry) & 171.8 & 15.5 & 295.5 & 26.5 & 19.6 & 40.5 & 50.2 & 22.6 \\
\hline & Tap Water & 175.5 & 18.6 & 330.5 & 28.2 & 19.0 & 44.2 & 54.0 & 24.2 \\
\hline & $\begin{array}{l}\text { Caborn } \\
\left(1 \mathrm{Cm}^{3} / \mathrm{L}\right.\end{array}$ & 182.5 & 20.2 & 346.2 & 31.5 & 16.0 & 47.2 & 58.8 & 32.2 \\
\hline & Elga 600 & 195.6 & 23.8 & 375.8 & 34.6 & 14.2 & 48.5 & 60.2 & 32.8 \\
\hline & $\begin{array}{l}\text { Caborn +Elga } \\
600\end{array}$ & 202.2 & 25.8 & 398.5 & 36.5 & 13.5 & 52.5 & 61.6 & 34.8 \\
\hline \multicolumn{2}{|c|}{ L.S.D. 5\% } & 2.04 & 0.90 & 12.12 & 0.43 & 0.07 & 1.05 & 1.12 & 0.33 \\
\hline
\end{tabular}




\section{3-3-Effect of interactions:-}

Data in Table (7) showed that protein and oil percentage of sunflower seeds $\mathrm{cv}$. Vidoc under the experimental conditions is. $23.8 \%$ and $34.6 \%$ respectively with planting seed of sunflower during $10^{\text {th }}$ September as a sowing date with spray Caboron+Elga 600.Also, Caborn +Elga 600 with planting seed of sunflower in the $10^{\text {th }}$ Septemberinteraction (202.2 and 398.5 kglfed.) respectively recorded the highest significant values followed by $\left(10^{\text {th }}\right.$ September + Elga 600$)$ and (caboron with the same sowing date) then (tap water during the late of sowing date) comparing width untreated plants dry seeds. The lowest values of oil \% comparing with control plants were recorded by dry seeds with planting sunflower plant in the $1^{\text {st }}$ August interaction. In the same direction mineral content $\mathrm{K}, \mathrm{Ca}$ and $P$ tack the braves' same trend. Whereas, Na content tack the adverts effect under different interaction treatments.

These results are in agreement with $\mathrm{Wu}$ et al. (1999) who revealed that $K$ and trace elements application increased $P$ concentration in soybean. This finding was in harmony with Ozoris et al. (1985) who reported that the concentration of $\mathrm{K}^{+}$and $\mathrm{Mg}^{+2}$ in sorghum plants were increased by application of $\mathrm{Zn}$ under calcareous soil and saline conditions. The role of $\mathrm{K}$ in the osmotic adjustment of plants under saline conditions and consequently its importance of being required to the selectivity and integrity of cell membrane was explained by Satti and Lopez, (1994).

The primitive effects of spraying plants with Elga and boron treatments increasing oil \% were achieved also by Sawan et al. (2006) on cotton plants. This may be attributed to the requirement of $\mathrm{P}$ for production of high quality seeds, since it involved in energy transfer reactions; energy is trapped in photosynthesis in form of ATP and NADP. Also, these results were found to be agree with those obtained by Rajendran and Veeraputhiran (2001) on sunflower plant.

\section{4- Endogenous hormones:-}

Data presented in Table (8) revealed that, all treatments enhanced the level of IAA in the leaves. Stimulatory marked effects were obtained by caboron + Elga 600 under the differences sowing date interaction or caborn with planting sunflower plant in the $10^{\text {th }}$ September as a sowing date. Application of dry seed (control) combination with planting during $1^{\text {st }}$ August as a sowing date showed less concentrations of IAA comparing with other treatments. These results are in confirmation with Marschner (1995) and Hitoshi et al. (1997) Who reported that $\mathrm{Zn}$ deficiency leads to the destruction of auxin and impairs its biosynthesis because $\mathrm{Zn}$ is required directly for the synthesis of tryptophan (precursor for the biosynthesis of IAA) and indirectly for the synthesis of auxins. Moreover, Zaghlool (2002) and Sakabutdinova et al. (2003) affirmed that foliar application increased IAA concentration. The same trend was obtained by Shakirova (2007).

It is obvious from Table (8) that, $\mathrm{GA}_{3}$ concentrations increased by all treatments compared with control plants. The highest $\mathrm{GA}_{3}$ concentrations were achieved by the application of caboron + Elga 600 (458.3 $\mathrm{mg} / 100 \mathrm{~g}$ fresh weight) under $10^{\text {th }}$ September as a sowing date followed by treatments of caboron + Elga 600 under $20^{\text {th }}$ August as a sowing date $(432.2 \mathrm{mg} / 100 \mathrm{~g}$ fresh weight) then caboron + Elga 600 (426.2 mg/100g fresh weight) under $1^{\text {st }}$ August as a sowing date. These simulative effects of treatments on growth promoters may due to the adjustment of the nutrients concentration which induces the synthesis of $\mathrm{CK}$ and $\mathrm{GA}_{3}$ required for growth (Amzallag et al., 1992).

In addition, ABA concentration was decreased by planting sunflower plant during $1^{\text {st }}$ August as a sowing date 
compared with the other different sowing date. Spray application treatments were detected the positive effect on ABA. Planting sunflower plant during $10^{\text {th }}$ September as a sowing date with all foliar application treatments which increased ABA level compared with the untreated plants (Table 8). Moreover, $10^{\text {th }}$ September as a sowing date gave a stimulatory effect on ABA concentration when applied with foliar application treatments. The maximum values were given by planting sunflower plant during $10^{\text {th }}$ September as a sowing date with elega 600 followed by the same sowing date with caboron + Elga 600 as a foliar application .

The high level of ABA under the experimental stress condition was in agreement with Masia et al (1994) who reported that $A B A$ accumulate in water stressed cotton and sunflower plants. The effect of Kon the accumulation of $A B A$ is well documented by Sakhabutdinova et al. (2003) and Shakirova (2007).

It could be seen that, the highest concentrations of IAA, GA 3 and ABA were achieved by $\mathrm{K}, \mathrm{N}, \mathrm{P}$ and $\mathrm{Mg}$ as a foliar treatments. Moreover, organic matter gave the maximum concentrations of IAA and a marked increase in $\mathrm{GA}_{3}$ and $\mathrm{ABA}$ concentrations. These results were accompanied by marked improvement in growth and yield indicating that, the interaction of planting sunflower during $1^{\text {st }}$ September as a sowing date with Elga (600) and boron as a foliar application created endogenous hormonal .

Table (8): Effect of the interaction between sowing dates and foliar application treatments interaction on IAA,GA3 and ABA ( $\mathrm{mg} / 100 \mathrm{gfw}$.) in leaves of sunflower plants at 50 days after planting under saline soil at Toshka conditions.

\begin{tabular}{|c|c|c|c|c|}
\hline \multicolumn{2}{|l|}{ Treatments } & $\begin{array}{c}\text { IAA } \\
\text { concentration } \\
\text { (mg /100gfw.) }\end{array}$ & $\begin{array}{c}\text { GA3 } \\
\text { concentration } \\
\text { (mg /100gfw.) }\end{array}$ & $\begin{array}{c}\text { ABA } \\
\text { concentration } \\
\text { (mg /100gfw.) }\end{array}$ \\
\hline \multicolumn{5}{|c|}{ Effect of interaction:- after } \\
\hline Sowing dates & Foliar & & & \\
\hline \multirow[t]{5}{*}{$1^{\text {st }}$ August } & Control (Dry) & 2.01 & 92.5 & 0.44 \\
\hline & Tap Water & 2.15 & 295.4 & 0.54 \\
\hline & Cab. $\left(1 \mathrm{Cm}^{3} / \mathrm{L}\right.$ & 4.58 & 419.6 & 0.62 \\
\hline & Elga600(1\2cmlL) & 2.55 & 300.6 & 0.85 \\
\hline & Cab.+Elga 600 & 8.66 & 426.2 & 0.75 \\
\hline \multirow[t]{5}{*}{$20^{\text {th }}$ August } & Control (Dry) & 2.26 & 95.6 & 0.86 \\
\hline & Tap Water & 2.42 & 300.0 & 1.04 \\
\hline & Cab. $\left(1 \mathrm{Cm}^{3} / \mathrm{L}\right.$ & 5.64 & 428.5 & 1.07 \\
\hline & Elga600 (1/2cm/ $)$ & 2.88 & 306.4 & 1.14 \\
\hline & Cab.+Elga 600 & 9.25 & 432.2 & 1.09 \\
\hline \multirow[t]{5}{*}{$10^{\text {th }}$ September } & Control (Dry) & 2.87 & 107.2 & 0.95 \\
\hline & Tap Water & 3.00 & 309.6 & 1.13 \\
\hline & Cab. $\left(1 \mathrm{Cm}^{3} / \mathrm{L}\right.$ & 6.52 & 449.4 & 1.25 \\
\hline & Elga6001/2cm/) & 3.42 & 324.5 & 1.53 \\
\hline & Cab.+Elga 600 & 11.63 & 458.3 & 1.44 \\
\hline
\end{tabular}




\section{REFERENCES}

Aboul-Magd, E.H. (1999). Physiological studies on the adaptation of some tomato varieties under saline condition. M.Sc. in Plant Physiology, Fac. of Agric., Ain Shams Univ., Cairo, Egypt.26-104.

Adiloglu, S. (2006). The effect of increasing nitrogen and zinc doses on the iron, copper and manganese contents of maize plant in calcareous and zinc deficient soils. Asian Journal of Plant Sciences, 5(3): 504-507.

Amzallag, G. N., H. R. Lerner and A. Poljakoff-Mayber (1992). Interaction Between Mineral Nutrients, Cytokinin and Gibberellic Acid During Growth of Sorghum at High $\mathrm{NaCl}$

A.O.A.C. (1984). Official Methods of Analysis. 12th Ed. Association Official Analysis Chemists, Washington, D.C., U.S.A.

Badawy, A.A.S. (1990). Studies on the effect of some growth regulators, macro and micro nutrientson some biochemical constituents of soybean under the condition of reclaimed soils.Ph.D. in Agricultural Biochemistry, Fac. of Agric., Ain Shams Univ., Cairo, Egypt.

Cakmak, I., C. Hengeler and H. Marschner (1994). Partitioning of shoot and root dry matter and carbohydrates in bean plants suffering from phosphorus, potassium and magnesium deficiency. J. Exp. Bot., 45: $1245-1250$.

Chapman, H.D. and P.F. Pratt. (1961). Methods of Analysis for Soils, Plant and Water Univ. of Calf. Division of Agric. Sci., $2^{\text {nd }}$ printing.

El-Bagouri, I.H., M.M. Wassif, M.A. El-Kadi and S.A. Sabet (1983). Response of barley to foliar application of some micronutrients under the conditions of saline water irrigation and highly calcareous soil. Desert Inst. Bull., A.R.E. 14: 1-15.

El-Baisary, E.M., M.M.B. El-Din and M.A. Negm (1981). A study on phosphorus fertilization of cowpea plant (Vigna sinensis, Savi.) in calcareous soil. Agricultural-Research-Review, 59(4): 267-278.

El-Baz, M. G. M. (1995). Effect of plant density on productivity of some sunflower varieties. Ph.D. Thesis. Fac. of Agric., Ain

El-Sadek, A.N.A., M.A. Ashoub, A.M. Abo Shetaia and M.T. Hegab (2004). Response of sunflower yield and its attributes to sowing dates, boron foliar application and nitrogen fertilization under El-Wadi El-Gadeed conditions. Zagazig J. Agric. Res. 31 (4A): 12571277.

El-Sawaby, M. and B.S. Zekri (1982). Contribution to the study of irrigation regime of sunflower. Agric. Res., Review. 60 (5): 289-298.

Gomez, K. A. and A. A. Gomez (1984). Statistical Procedures for Agriculture Research. A Wiley- Inter Science Publication, John Wiley \& Sons, Inc. New York, USA.

Harmati, I. (1993). Effect of fertilizers onsunflower yields.Agrokemia-esTalajtan, 42(3-4): 282-292.

Hegazy, A.M.A. (2004). Physiological studies on some plants grown under calcareous soil conditions. Ph.D. in Plant Physiology, Fac. of Agric., Ain Shams Univ., Cairo, Egypt. , 42-75.

Hitoshi, S., M. Hoshi, T. Nomura and T. Yokota (1997). Zinc Deficiency Affects the Levels of Endogenous Gibberellins in Zea mays L. Plant and Cell Physiology, Short Communication, 38(9): 1087-1090.

Johnson, C.M. and A. Ulrich (1959). Analytical methods for use in plants analysis. U.S. Dept., Agric. Calif. Univ. Agric. Inform. Bull., 766.

Kishk, E. T.; A. A. Robishy and O.M. Ali (1985). Utilization of some micronutrients as aregulator for growth of Sudan-Grass plants,grown under saline and calcareous soil conditions. Desert Inst. Bull., 35(1):219-231. 
Lowry, O.H.; N.J. Rosebrough; A.L. Farr and R.J. Ranall (1951). Protein measurements by folinfenol reagent. $\mathrm{J}$. Biol. Chem., 193: 265-275.

Marschner, H. (1995). Mineral Nutrition of Higher Plants. Second Edition, London, UK: Academic Press.

Masia, A., A. Pitacco, L. Braggio and C. Giulivo (1994). Hormonal responses to partial drying of the root system of Helianthus annuus. J.exp. Bot., 45: 6976.

Mekki, B.B., M.A. El-Kholy and E.M. Mohamed (1999). Yield, oil and fatty acids content as affected by water deficit and potassium fertilization in two sunflower cultivars. Egypt. J. Agron.21: 67-85.

Muriel, J.I., R. Cimeneg and I. Berengena (1977). Yield of sunflower in field plots in response to various watering regime and to irrigation during critical phases of growth. In proceeding of the $6^{\text {th }}$ international sunflower Conference. Bucharest Romania, International sunflower Association. (un dated) 577582. (C.F. Field Crop Abst. 30: 7889).

Murphy, J. and J.H. Riley (1962). A modified single solution method for the determination of phosphate in natural waters. Anal. ChimActa, 27:31 - 36.

Obreza, A.T., A.K. Alva and D.V. Calvert (1993). Citrus fertilizer management on calcareous soils. Series of soil and water science, Florida, USA. Ser.1127, pp1-10.

Ozoris, M. A., A. A. Robishy, K. Reda and E. T. Kishk (1985). Effect of K, Ca and Mg foliar application on yield and chemical composition of sorghum under salinity conditions. Desert Inst. Bull., 35 (2): 567582.

Rajendran, K. and R. Veeraputhiran (2001). Phosphorus nutrients in sunflower. Agric. Rev., 22: 68-70.

Reddy, G.S., V. Maruthi, M. Vanaja and D. G. Rao (1998). Effect of moisture stress and management practices on productivity of rainfed sunflower
(Helianthus annuusL.). Indian $\mathrm{J}$. of Agron. 43 (1): 149-153.

Russell, E. W. (1973). Soil condition and plant growth. The English Language Book Society and Longman, London.(C.F. Sawan et al. 2006).

Sakhabutdinova, A. R, D. R. Fatkhutdinova, M. V. Bezrukova and F. M. Shakirova (2003). Salicylic acid prevents the damaging action of stress factors on wheat plants. Bulg. J. Plant Physiol., Special issue. 314-319

Sakr, A.A., S.A. Rizk and S.A. Mahmoud (1990). Growth and uptake responses of plants to zink as influenced by phosphorus fertilization. Annals-ofAgricultural-Science-Cairo, 35(1):587594.

Salama, A.M.(1987). Yieldand oil quality ofsunflowers as affected by fertilizers and growth regulators.Novenytermeles, 36(3): 191-202.

Sangakkara, U.R., M. Frehner and J. Nösberger (2000). Effect ofsoil moisture and potassium fertilizer on shoot water potential, photosynthsis and partitioning of carbon in mungbean and cowpea. J. Agron. Crop Sci., 185:201-207.

Sarkar, R.K. and B. Bhattacharya. 1980. Response of sunflower to soil moisture regimes in the Gangetic alluvium soil conditions of eastern India. Indian Agriculturist. 24 (2): 89-93.

Satti S. M. and M. Lopez (1994). Effect of increasing potassium levels for alleviating sodium chloride stress on the growth and yield of tomatoes. Commun. Soil Sci. Plant Anal. 25 (15\&16): 2807- 2823.

Sawan, Z. M., S. A. Hafez, A. E. Basyony and A. R. Alkassas (2006). Cottonseed, Protein, Oil Yields and Oil Properties as Influenced by Potassium Fertilization and Foliar Application of Zinc and Phosphorus. World Journal of Agric. Sci., 2 (1): 66-74.

Schlenk, H. and J. L. Gelerman (1960). Esterification of fatty acids with diazomethane on a small scale. Anal. Chem., 32: 1412-1414. 
Shakirova, F. M. (2007). Role of Hormonal System in the Manifestation of Growth Promoting and Antistress Action of Salicylic Acid. In: S. Hayat and A. Ahmad. Salicylic Acid: A Plant Hormone. Springer Netherlands. , 69-89

Tamak, J.C., H.C. Sharma and K.P. Singh (1997). Effect of phosphorus, sulphur and boron on seed yield and quality of sunflower (Helianthus annuus L.). Indian J. Agron. 42 (1): 173-176.

Vitkov, M. (1976). Irrigation and water requirements of sunflower grown on podzolized chernozem siols. Resteniev Dni-Nauk. 13 (1) : 103-111.

Vyakaranahal, B. S., M. Shekhargouda, S. A Patil, A. S. Prabhakar and K. Giriraj (2001). Effects of planting date and chemicals (TIBA and boron) spray on seed yield, its attributes and quality of single and three ways cross sunflower hybrids during different seasons. Seed Res. 29 (2): 127-135 (C. F. CAB Abstracts 2002).

Weiss, E.A. (2000). Oilseed Crops. Second Edition, Blackwell Science. Australia. pp. 205-243.

Wu, M.C., C.Z. Xiao and P.Y. Zheng (1999).Study of the physiological function of phosphorus in soybean. Scientia Agricultura Sinica, 32(3):59-65.

Zaghlool, S.A.M. (2002). The effect of gibbrellic acid $\left(\mathrm{GA}_{3}\right)$, salicylic acid (SA), sperimidine (Spd) and methodes of application on growth, yield, some chemical constituents and some phytohormones in mungbean(Vigna radiata L.). ArabUniv. J. Agric. Sci., Ain Shams Univ., Cairo, 10(2):493-504.

\section{أقلمة وتحسين نبات عباد الثمس تحت ظروف الإجهاد البيئى بمنطقة توشكا




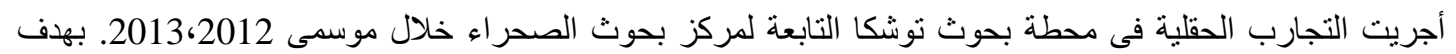

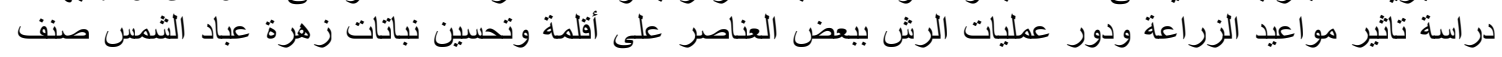

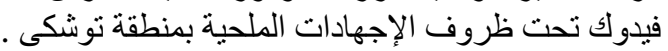

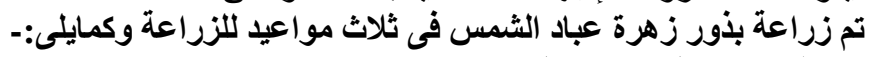

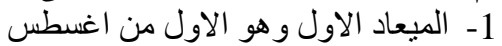

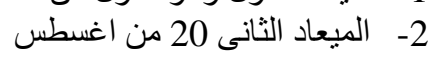
3- الميعاد الثالث 10 من سبتمبر

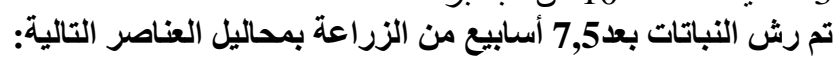

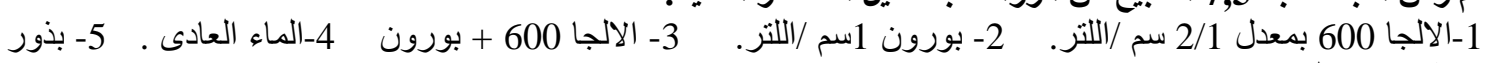

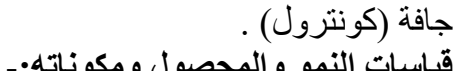

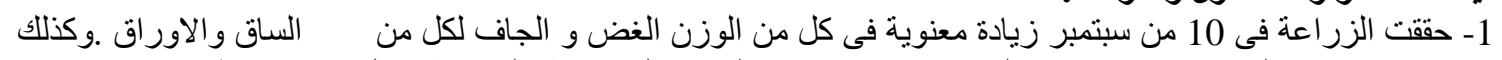

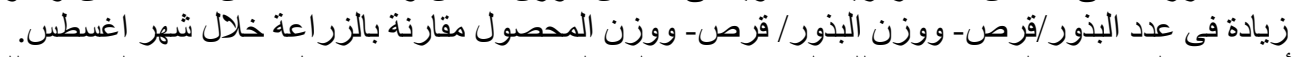

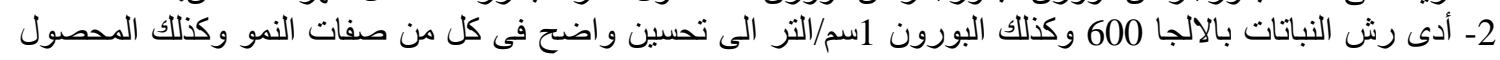

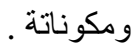

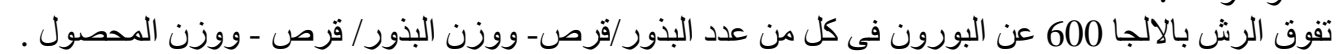

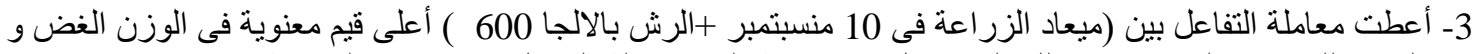

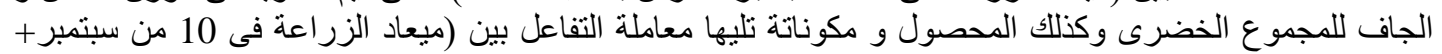

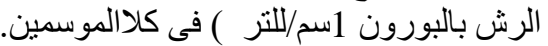

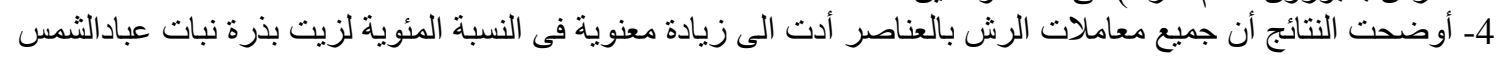

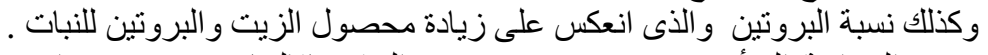

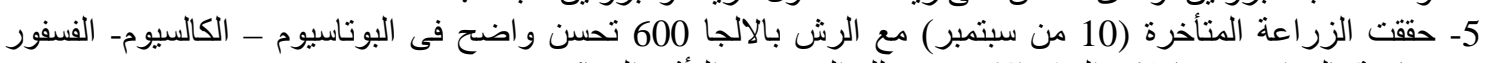

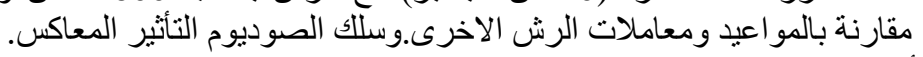

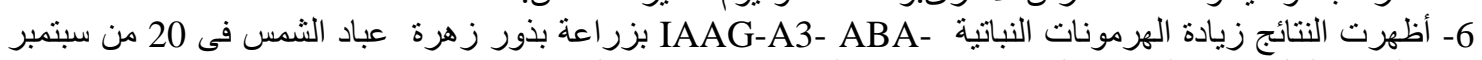
(الميعاد الثالث) مع الرش بالالجا 600 مقارنة بالمو اعيد ومعاملات الرش الاخرى. 
